\title{
Multiple Intelligence in the Perspective of the Qur'an
}

\section{Husnaini ${ }^{1}$, Ahmad Syauqi Fuady ${ }^{2}$, Irnie Victorynie ${ }^{3}$}

${ }^{1,3}$ International Islamic University Malaysia, ${ }^{2}$ STIT Muhammadiyah Bojonegoro ${ }^{1}$ hus_surya06@yahoo.co.id, ${ }^{2}$ syauqi.asf68@gmail.com, ${ }^{3}$ victorynie@gmail.com

\begin{abstract}
This is a qualitative-descriptive analytic research aims to explore cues in the Qur'an that describe the concept of multiple intelligences. In Islam, the Qur'an is a complete guide for life. Indeed, many books that talk about multiple intelligences. However, there hasn't been a book that specifically explain multiple intelligences according to the perspective of the Qur'an. This qualitative research used a literature review (research library) — data obtained through a literary approach in library data collection. The data were then analyzed using a thematic interpretation approach (maudhu'i). The results of this study: (1) deep linguistic intelligence-Nisa: 82, Al-Baqarah: 171, Al-An'am: 50, Ali Imran: 7; (2) Logicalmathematical intelligence in Al-Waqiah: 58-59, Al-Insan: 2, Ar-Ra'du: 3, AlAnbiya: 30, An-Nur: 43; (3) visual-spatial intelligence in Ar-Ra'du: 3, Qaf: 7-8; (4) kinesthetic intelligence in Al-Baqarah: 219, Yasin: 68; (5) musical intelligence in Asy-Syuara: 221-227; (6) intrapersonal intelligence in Adz-Dzariyat: 21, AlBaqarah: 44, Yasin: 62, Al-Mulk: 10; (7) interpersonal intelligence in Ar-Rum: 21, Al-Baqarah: 76, Ali Imran: 118; (8) naturalist intelligence in Al-Baqarah: 164, An-Nahl: 11, An-Nahl: 69, Al-Ghasyiyah: 17; (9) existentialist intelligence in Yunus: 24, Az-Zumar: 42, Al-Baqarah: 269. Researchers suggest educational institutions should add new insights regarding their learning strategies with multiple intelligences, especially those whose source of inspiration is the Qur'an and to other researchers should examine concept of musical intelligence, interpersonal intelligence, and naturalist intelligence perspective of the Qur'an.
\end{abstract}

\section{Keywords: Al-Qur'an, Compound Intelligence}

Abstrak
Penelitian ini merupakan analisis deskripsi kualitatif yang bertujuan untuk
mengeksplorasi isyarat Al-Quran yang menggambarkan tentang konsep
kecerdasan majemuk. Dalam Islam, Al-Qur'an adalah pedoman hidup yang
lengkap. Memang banyak buku yang membahas kecerdasan majemuk, namun
belum ada buku khusus yang secara khusus menjelaskan kecerdasan majemuk
dalam perspektif Al-Qur'an. Penelitian kualitatif ini menggunakan studi pustaka,
data diperoleh melalui pendekatan sastra dalam pengumpulan data perpustakaan.
Data tersebut kemudian dianalisis menggunakan pendekatan interpretasi tematik
(maudhu'i). Hasil penelitian ini adalah: (1) kecerdasan linguistik dalam-Nisa: 82,
Al-Baqarah: 171, Al-An'am: 50, Ali Imran: 7; (2) Kecerdasan logis-matematis
dalam Al-Waqiah: 58-59, Al-Insan: 2, Ar-Ra'du: 3, Al-Anbiya: 30, An-Nur: 43;
(3) kecerdasan visual-spasial dalam Ar-Ra'du: 3, Qaf: 7-8; (4) kecerdasan


kinestetik dalam Al-Baqarah: 219, Yasin: 68; (5) kecerdasan musik di AsySyuara: 221-227; (6) kecerdasan intrapersonal dalam Adz-Dzariyat: 21, AlBaqarah: 44, Yasin: 62, Al-Mulk: 10; (7) kecerdasan interpersonal dalam ArRum: 21, Al-Baqarah: 76, Ali Imran: 118; (8) kecerdasan naturalis dalam AlBaqarah: 164, An-Nahl: 11, An-Nahl: 69, Al-Ghasyiyah: 17; (9) kecerdasan eksistensialis dalam Yunus: 24, Az-Zumar: 42, Al-Baqarah: 269. Peneliti menyarankan lembaga pendidikan harus menambah wawasan baru mengenai strategi pembelajarannya dengan kecerdasan majemuk, terutama yang sumber ilhamnya adalah Alquran dan Bagi peneliti lain sebaiknya mengkaji konsep kecerdasan musik, kecerdasan interpersonal, dan kecerdasan naturalis perspektif Alquran.

\section{Kata Kunci: Al-Qur'an, Kecerdasan Majemuk}

\section{Introduction}

From Plato, Aristotle, Darwin, Alfred Binet, Stanberg, Piaget, and Howard Gardner, various theories of intelligence emerged. ${ }^{1}$ Intelligence is defined as the general mental ability to learn and apply knowledge in manipulating the environment and the ability to think abstractly. Intelligence includes the ability to adapt to new environments or changes in the environment, evaluate and assess, the ability to understand complex ideas, the ability to think productively, the ability to learn quickly, learn from experience, and the ability to understand relationships. ${ }^{2}$ Intelligence is more of a hereditary instinct and habit or an acquired adaptation to repeat a situation, which begins with empirical trial and error. ${ }^{3}$

A popular theory of intelligence is an IQ (intelligence quotient) based intelligence test coined by French psychologist Alfred Binet. Since then, the IQ test has genuinely become a scientific tool that is believed to determine students' success or failure in the future. ${ }^{4}$ However, in its development, the IQ test coined by Alfred Binet has drawn sharp scrutiny by scientists. The criticism expressed that the IQ test connects the intelligence factor with heredity (eugenic). The grouping of IQ test results in static groups of numbers clearly shows this fact. ${ }^{5}$

Intelligence is not static or eternal. Intelligence is not only a matter of genetics or heredity but is also influenced by the environment and experiences experienced by

\footnotetext{
${ }^{1}$ Munif Chatib, Sekolahnya Manusia: Sekolah Berbasis Multiple Intelligences di Indonesia (Bandung: Kaifa, 2014), 69-70.

${ }^{2}$ Muhammad Yaumi, Pembelajaran Berbasis Multiple Intelligences (Jakarta: Dian Rakyat, 2012), 9-10.

${ }^{3}$ Muhammad Yaumi, Pembelajaran Berbasis Multiple Intelligences, 10.

4 Howard Gardner, Multiple Intelligences (Kecerdasan Majemuk): Teori dalam Praktik (Tangerang: Interaksara, 2013), 21.

${ }^{5}$ Munif Chatib, Sekolahnya Manusia,72-73.
} 
individuals. For example, Daniel Goleman argues that proficiency, in essence, can be viewed as a coordinated set of habits, what we think, feel, and do, so that a task is accomplished. ${ }^{6}$

Therefore, since the early 1970s, some psychologists have argued that the IQ test applied in education is invalid. They then developed new intelligence concepts that criticized the IQ test, including a follow-up test called the SAT (scholastic aptitude test) and WRAT (exhaustive range achievement test). Among the new popular concepts of intelligence are the general quotient (general intelligence) by Charles Spearman; fluid and crystallized quotient (liquid and crystal intelligence) by Raymond Cattel and John Horn; modifiable quotient (intelligence can be modified) by Reuven Feurstein; proximal quotient (proximal intelligence) by Leo Vygotsky; learnable quotient (intelligence that can be learned) by David Perkins; behavior quotient (behavioral intelligence) by Arthur Costa; spiritual quotient (spiritual intelligence) by Danah Zohar and Ian Marshall; moral quotient (moral intelligence) by Robert Coles; triarchic quotient (trinity intelligence) by Robert J Sternberg; emotional quotient (emotional intelligence) by Daniel Goleman; adversity quotient (intelligence solving difficulties) by Paul Scholtz. ${ }^{7}$

The explanation above shows that the concept of intelligence is no longer based on numbers. The psychological concept of intelligence is comprehensive, as broad as the secrets of human intelligence itself. When human intelligence is only assessed in numerical units, intelligence will narrow in the meaning of the numbers themselves. Therefore, the development of theories of intelligence is currently moving in a more human direction. ${ }^{8}$

The consequence is that intelligence's meaning cannot be limited by the indicators contained in the formal test (achievement test). On the contrary, human intelligence must be viewed from many dimensions. Not only from linguistic and logical-mathematical intelligence. The so-far exalted IQ test can only measure linguistic and logical-mathematical abilities. ${ }^{9}$ Not surprisingly, based on the results of a survey in the United States in 1918 on IQ, a dangerous paradox has been found. When the children's IQ scores there increased, it turned out that their emotional intelligence decreased. ${ }^{10}$

In this context, a concept of intelligence called multiple intelligences by Howard Gardner emerged. Through the concept of multiple intelligences (multiple intelligences) that

\footnotetext{
${ }^{6}$ Daniel Goleman, Working with Emotional Intelligence (London: Bloomsbury Publishing, 2009), 289.

${ }^{7}$ Howard Gardner, Multiple Intelligences, 6.

${ }^{8}$ Munif Chatib dan Alamsyah Said, Sekolah Anak-Anak Juara Berbasis Kecerdasan Jamak dan Pendidikan Berkeadilan (Bandung: Kaifa, 2012), 69.

${ }^{9}$ Howard Gardner, Multiple Intelligences, 35.

${ }^{10}$ Ary Ginanjar Agustian, Rahasia Sukses Membangun Kecerdasan Emosi dan Spiritual ESQ (Emotional Spiritual Quotient) Berdasarkan 6 Rukun Iman dan 5 Rukun Islam (Jakarta: Penerbit Arga, 2001), x1iv.
} 
Howard Gardner made a sharp criticism of the IQ test coined by Alfred Binet. According to Howard Gardner, human intelligence can be observed from human habits in making new products with cultural values (creativity) and habits for solving problems (problem-solving) independently. ${ }^{11}$ In the beginning, the concept of multiple intelligence was in the spotlight because the term multiple intelligence was drawn from the realm of psychology to education, which means that every student has different potential and intelligence. ${ }^{12}$

Howard Gardner chose the term multiple (compound) for the concept of his findings. He did not assign a specific label to the meaning of intelligence, as did earlier originators of the concept of intelligence, in order to allow the realm of human intelligence to continue to be developed. ${ }^{13}$ Evidently, in the book Frame of Mind, published in 1983, Howard Gardner triggered seven intelligence kinds. ${ }^{14}$ Then, in the book Intelligence Reframed, published in 1999, he stated that the human brain has at least nine intelligence types consisting of:

1. Linguistic intelligence. Namely, the ability to think in the form of words or use language to express and appreciate complex meanings, as possessed by writers or poets.

2. Logical-mathematical intelligence. Namely the ability to count, measure, consider propositions and hypotheses, and complete numerical operations, as possessed by scientists or accountants.

3. Visual-spatial intelligence. Namely, the sensitivity to explore the imagination, modify an object's image, and carry out transformations in various forms appropriately, as owned by a painter orsailor.

4. Kinesthetic intelligence. Namely, the skills to move, cultivate, and control the body in certain forms of movement, as owned by an athlete ordancer.

5. Musical intelligence. Namely, the sensitivity to recognize tone patterns, melodies, rhythms, and rhythms is like a singer or music player.

6. Intrapersonal intelligence. Namely, the ability to understand and motivate oneself, then act on that understanding, as possessed by the theologian or philosopher.

7. Interpersonal intelligence. Namely, the ability to understand others' thoughts, attitudes, behavior, and desires, as possessed by a counselor or politician.

\footnotetext{
${ }^{11}$ Howard Gardner, Multiple Intelligences, 34.

12 Annas Ribab Sibilana, "Pendidikan Karakter Melalui Pembelajaran Berbasis Multiple Intelligences di Markaz Arabiyah Pare Kediri," Indonesian Journal of Islamic Education Studies (IJIES), Volume 3, Nomor 1, Juni 2020, 48-62, https://doi.org/10.33367/ijies.v3i1.1123.

${ }^{13}$ Munif Chatib, Sekolahnya Manusia, 75.

${ }^{14}$ Howard Gardner, Multiple Intelligences, 38.
} 
8. Naturalist intelligence. Namely, sensitivity to the surrounding environment, which enjoys its beauty, is also a concern for preserving it, as owned by astronauts or farmers.

9. Existentialist intelligence. Namely, the ability to build a strong awareness of life after death, as possessed by prophets and apostles. ${ }^{15}$

Al-Qur'an is a guide and guidance for life that is always relevant in every time and age. Al-Qur'an is a holy book which, among other things, functions as a guide $(H u d \bar{a})$, explanation (bayyinah), and differentiator (furqān) for believers. Therefore, for Muslims, the Qur'an is a reference in life. The Qur'an contains many hints about humans and science. No exception is a sign of multiple intelligences that exist in humans. The scientific signs in the Qur'an are interesting to study and ponder. Thus, so that their contemplation and searches do not get lost, believers are required to make the Al-Qur'an their main inspiration and reference.

Research conducted by Hofur shows that many signs of multiple intelligence are found in the Qur'an. Linguistic intelligence (al-Baqarah: 31-33), logical-mathematical intelligence (al-Ankabut: 43), visual-spatial intelligence (Hud: 37-38), kinesthetic intelligence (al-Maidah: 31), interpersonal intelligence (al -Hujurat: 13), intrapersonal intelligence (ad-Dzariyat: 21), naturalist intelligence (Ali Imran: 190-191), existential intelligence (ad-Dzariyat: 56). ${ }^{16}$

Masjudin and Syahyudin suggest the sources of the Qur'an and Hadith relating to multiple intelligence: linguistic intelligence (al-Baqarah: 33, ar-Rahman: 4), logicalmathematical intelligence (al-Ankabut: 43), visual intelligence (ar-Ra'du: 3), kinesthetic intelligence, Bukhari's Hadith history, intrapersonal intelligence (adz-Dzariyat: 21), interpersonal intelligence (Ali Imran: 134), naturalist intelligence (al-Baqarah: 30) ${ }^{17}$. Linguistic intelligence (al-Baqarah: 33; ar-Rahman: 1-4), logical-mathematical intelligence (al-Ankabut: 43), interpersonal intelligence (al-Ma'un: 1-3), spiritual existential intelligence (al- Fatihah: 6). ${ }^{18}$

\footnotetext{
${ }^{15}$ Munif Chatib dan Alamsyah Said, Sekolah Anak-Anak Juara, 101.

${ }^{16}$ Hofur, "Konsep Multiple Intelligences Perspektif Al-Quran/Hadis dan Implikasinya terhadap Pembelajaran PAI," (Skripsi, Jurusan Pendidikan Agama Islam Fakultas Tarbiyah dan Ilmu Pendidikan UIN Sunan Kalijaga Yogyakarta, 2018): 107-110.

${ }^{17}$ Masjudin dan Syahyudin, "Teori Kecerdasan Majemuk (Multiple Intelligence) dan Teori Kecerdasan Emosi (Emotional Intelligence) serta Relevansinya dengan Konsep Pendidikan Islam," Ta'dib, Volume 15, No I (JanJuni 2017): 73-75, https://jurnal.iaihnwpancor.ac.id/index.php/tadib/article/view/179.

18 Muhammad Anas Ma'ruf dan Eka Deni Sulistyanik, "Pengembangan Potensi Peserta Didik dalam Pembelajaran Pendidikan Agama Islam Berbasis Kecerdasan Majemuk (Multiple Intelligence)," Al-Tarbawi Al-Haditsah: Jurnal Pendidikan Islam, Vol. 4, No. 2, Desember 2019: 81-105, doi:10.24235/tarbawi.v4i2.5216.
} 
Azis Abdullah compared the concept of multiple intelligences in the perspective of the Qur'an and the West. The results found 14 multiple intelligences based on studies in the Qur'an. According to Howard Gardner, nine bits of intelligence are similar to the nine bits of intelligence, namely: language intelligence, thinking intelligence, heart intelligence, life intelligence, social intelligence, body intelligence, painting intelligence, art intelligence, natural exploration intelligence. Besides, Azis Abdullah also added five multiple intelligences in the perspective of the Qur'an that is not found in Howard Gardner's theory, namely: spiritual intelligence, entrepreneurial intelligence, leadership intelligence, moral intelligence, and performance intelligence. ${ }^{19}$

This research article is entitled The Concept of Multiple Intelligence in the Perspective of the Qur'an. As the title implies, this article intends to explore the signs in the Qur'an that describe the concept of multiple intelligences by referring to verses in the Qur'an.

\section{Methods}

This research is a type of library research, which uses written materials as a unit of analysis $^{20}$. The data obtained were then described qualitatively in the descriptive form in the form of written data. ${ }^{21}$ In other words, not using numbers but using words or sentences. ${ }^{22}$ Descriptive qualitative research also describes the object concerning the problem under study without questioning the relationship between research variables. ${ }^{23}$

Meanwhile, the approach used in this research is the interpretive approach with the thematic method (Maudhui). The thematic method, according to M Quraish Shihab's explanation, is a method that directs the view to a particular theme, then seeks the view of the Qur'an on that theme by compiling all the verses, while enriching them with traditions, to be summed up in one view. Thorough regarding the themes discussed. ${ }^{24}$

The primary data source of this research is Al-Qur'an. The Qur'an used as a guide is: First, the Qur'an and its translation, the Ministry of Religion of the Republic of Indonesia and the Government of the Kingdom of Saudi Arabia, Without Years. Second, Muhammad

\footnotetext{
${ }^{19}$ Azis Abdullah, "Perbandingan Kecerdasan Majemuk (Perspektif Al-Quran dan barat)," Al-Manar: Jurnal Komunikasi dan Pendidikan Islam, Volume 7, Nomor 2, Desember 2018: 23-40, https://doi.org/10.36668/jal.v7i2.88.

${ }^{20}$ Abuddin Nata, Metodologi Studi Islam (Jakarta: Raja Grafindo Persada, 2002), 125.

${ }^{21}$ Lexy J. Moeloeng, Metodologi Penelitian Kualitatif (Bandung: Remaja Rosdakarya, 2003), 4.

${ }^{22}$ Sutrisno Hadi, Metodologi Research (Yogyakarta: Andi Offset, 1995), 66.

${ }^{23}$ Sanapiah Faisol, Format-Format Penelitian Sosial (Jakarta: Rajawali Press, 1992), 18.

${ }^{24}$ M Quraish Shihab, Kaidah Tafsir: Syarat, Ketentuan, dan Aturan yang Patut Anda Ketahui dalam Memahami Ayat-Ayat Al-Qur'an (Tangerang: Lentera Hati, 2013), 385.
} 
Thalib, Al-Qur'an Tarjamah Tafsiriyah: Understanding the Meaning of the Quran Easier, Quicker, and Accurately, Yogyakarta: Publisher Ma'had An-Nabawy, 2012. Meanwhile, secondary data sources are books, books, newspapers, magazines, websites, websites, etc. Because the Qur'an study requires a reference to the meaning of the word, several Arabic dictionaries are used. The Al-Qur'an Index is used to track certain verses and words in the Qur'an related to the subject matter. Several software and applications, such as KBBI Online, Arabic Dictionary, English Dictionary, and Maktabah Syamilah, are used as support.

Data collection techniques used in library research are literary, namely by collecting library materials related to the object of discussion studied. ${ }^{25}$ After the required data is collected, the data processing process is carried out by going through three stages as follows: editing, organizing, and finding the results of the research. The results obtained are then concluded. ${ }^{26}$

In line with the thematic interpretation method's steps, the authors took three stages of data analysis techniques. ${ }^{27}$ First, selecting critical terms from the vocabulary of the Qur'an that describes intelligence. Second, determine the basic meaning and the meaning of nasabi (relational meaning). The central meaning is related to the meaning of language or semantics. The meaning of nasabi is an additional meaning per the context of the sentence in which the term is located.

Third, conclude and look for the hidden meaning of all the concepts obtained. In this stage, a meaningful and reflective mindset is used. The mindset of meaning is an attempt to grasp the meaning behind the express, look for the implied meaning of the verses and concepts of the Qur'an, and relate it to related matters that may be logical-theoretical, maybe ethical, or transcendental. ${ }^{28}$ This mindset takes place between the Qur'an text and the study of theories that exist in Muslim intellectual realms to be used as a supporting tool in understanding the meaning contained in the verses of the Qur'an, not the verses of the Qur'an which are adapted to the theory -the theory or opinions of scholars and scholars. ${ }^{29}$

\footnotetext{
${ }^{25}$ Suharsimi Arikunto, Prosedur Penelitian: Suatu Pendekatan Praktek (Jakarta: Rineka Cipta, 1990), 24.

${ }^{26}$ Imam Suprayogo dan Tobroni, Metodologi Penelitian Sosial-Agama (Bandung: Remaja Rosdakarya, 2003), 135.

${ }^{27}$ Jalaluddin Rakhmat, Konsep-Konsep Antropologi dalam Budhy Munawar-Rachman (ed.), Kontekstualisasi Doktrin Islam dalam Sejarah (Jakarta: Paramadina, 1995), 75.

${ }^{28}$ Noeng Muhadjir, Metodologi Penelitian Kualitatif (Yogyakarta: Penerbit Rake Sarasin, 2000), 93.

${ }^{29}$ Baharuddin, Paradigma Psikologi Islami: Studi tentang Elemen Psikologi dari Al-Quran (Yogyakarta: Pustaka Pelajar, 2007), 41.
} 


\section{Discussion}

In the Qur'an, all words that have the meaning of intelligence are not used. A clear definition of intelligence is also not found in the Qur'an. Nevertheless, through the words used by the Qur' an, we can infer the meaning of intelligence. Among the widely used words by the Qur'an are words that have a meaning close to intelligence, such as words that are similar to the words al-'aql, al-lubb, al-bașār, an-nuha, al-fiqh, al-fikr, al-nazar, altadabbur, al-zikr, al-'ilm. These words are widely used in the Qur'an in verbs, such as the word ta'qilūn. Muhammad Ali Al-Shabuni, interpreting the word afala ta'qilūn, "are you not using your mind." ${ }^{30}$ Thus, according to the Qur'an, intelligence is measured by using that reason or intelligence for positive things for oneself and others.

After knowing the meaning of intelligence in the Qur'an perspective based on the words that are widely used by the Qur'an as mentioned above, the author will reveal what the Quranic concept of multiple intelligences is actually about.

1. Linguistic Intelligence

There are so many verses of the Qur'an that motivate people to have linguistic intelligence, especially the Qur'an language. Among the widely used words are words tadabbur, which means contemplating and understanding, as Surah An-Nisa: 82 follows:

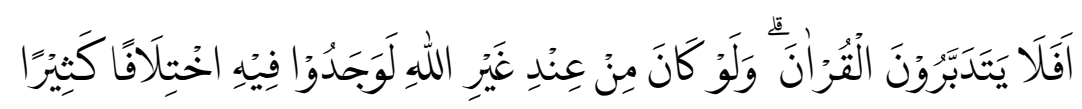

"Then do they not pay attention to the Quran? If the Qur'an were not from Allah's side, they would have found many contradicting verses in it." (Surah An-Nisa: 82)

Another word of God that deals with linguistic intelligence or language intelligence and word use tadabbur can also be listened to in Surah Al-Mukminun: 68, Shad: 29, Muhammad: 24. Al-Qur'an also uses the word ya'qilūn and ta'qilūn in motivating linguistic intelligence, as in the following surah:

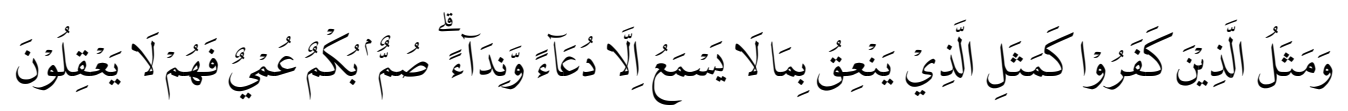

"And the parable (of the people who call) the unbelievers is like the shepherd who calls the beast who hears nothing but calls and cries. They are deaf, mute, and blind, so (therefore) they do not understand." (Surah Al-Baqarah: 171)

The same verse of the Qur'an also uses the word ya'qilün and ta'qilün contained in surah Al-An'am: 151, Al-Anfal: 22, Yunus: 42, Ar-Rum: 28, and Az-Zukhruf: 3. Some

\footnotetext{
${ }^{30}$ Muhammad Ali Al-Shabuni, Shafwah Al-Tafasir, Juz I (Beirut: Dar Al-Fikr, 1988), 576.
} 
use the word yatafakkarūn, as in surah Al-An'am: 50, Yunus: 24, An-Nahl: 44, Al-Hashr: 21.

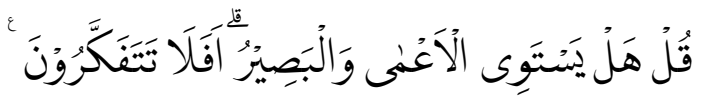

"Say, is it the same as a person who is blind and someone who sees? Don't you guys think about it?" (Surah Al-An'am: 50)

Using the word ulu al-albāb as in surah Ali Imran: 7, Shad: 29, Az-Zumar: 18.

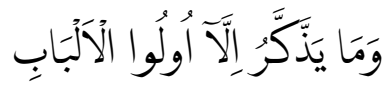

"And cannot take a lesson (thereof) but people who are wise." (Surah Ali Imran: 7)

\section{Logical-Mathematical Intelligence}

Lots of verses talk about scientific cues, or it can be said to imply logicalmathematical intelligence. Al-Qur'an talks at length about humans, and one of the things described is the issue of human reproduction and the stages through which it was created as a human. The following are among the verses on this subject, especially concerning sperm and ova.

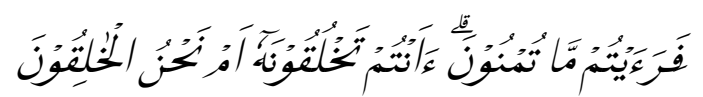

"Then explain to Me about the nutfah that you emit (mani). Did you create it or us?" (Surah Al-Waqiah: 58-59)

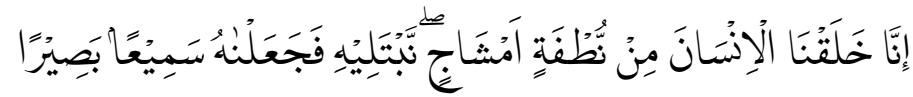

"Indeed, We have created man from a drop of semen mixed (between the male seed and the female seed). We want to test it (with orders and prohibitions). Therefore We make him hear and see. "(Surah Al-Insan: 2)

The Qur'an talks about the creation of earth on which there are mountains, rivers, various kinds of fruit in pairs - male and female, bitter and sweet, black and white, large and small - and the phenomenon of daytime and night, all of which can encourage humans to use their logical-mathematical intelligence to carry out scientific research.

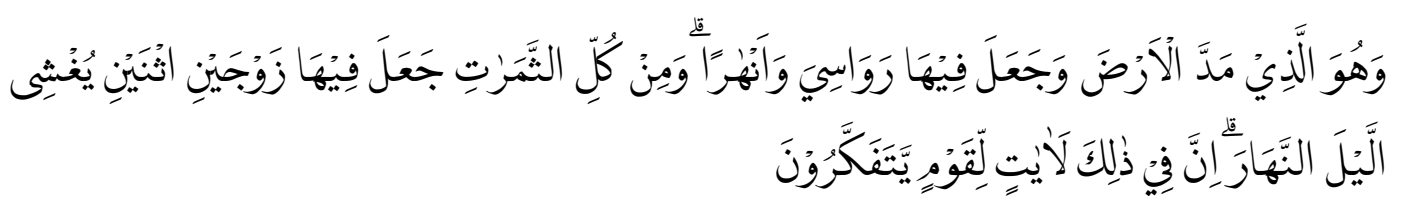

"And He is the Lord who stretched the earth and made the mountains and rivers and made all the fruit in pairs on it. Allah closed the night to the day. Indeed, in this, there are signs (the greatness of Allah) for those who think." (Surah Ar-Ra'du: 3) 
The signal of the suggestion that humans have another logical-mathematical intelligence is the Qur'anic explanation that the heavens and the earth were once a lump, through the word of Allah:

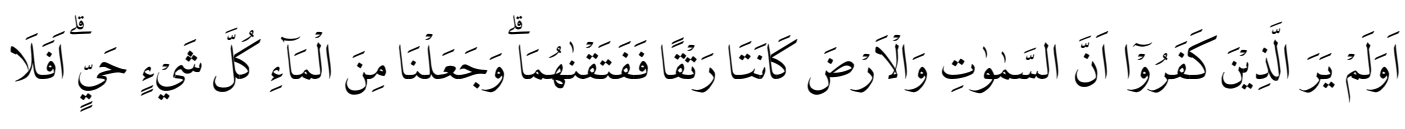

"And do those who disbelieve do not know that the heavens and the earth were both once substantial, then We separated the two, and from the water, We made all living things. So why do they not also believe?" (Surah Al-Anbiya: 30)

We also consider how the Qur'an explains about clouds and the process of rain in the following verse:

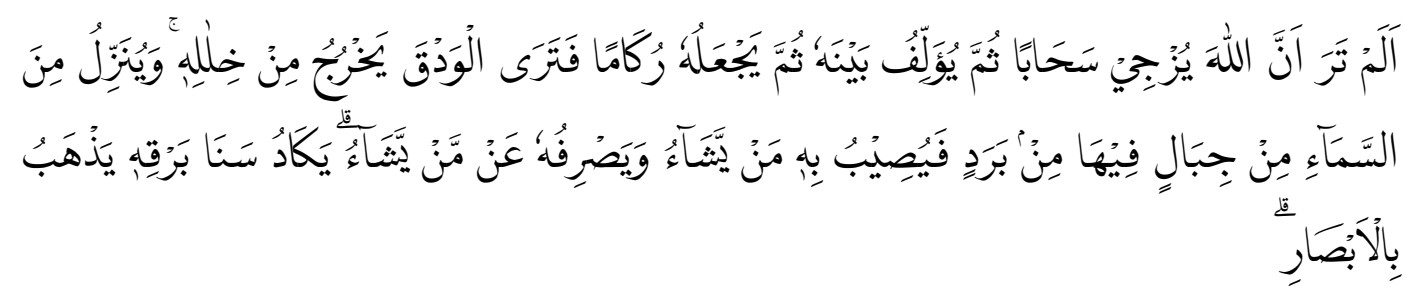

"Do you not see how Allah paraded the cloud, then gathered between (parts) of it, then made them overlap, then you saw the rain coming out of the gaps (clouds). Allah also sent down (particles) of ice from the sky, (that is, from clouds like) mountains, so that the ice (droplets) on whom He wanted and turned away from whom He wanted. The radiance of lightning almost lost sight." (Surah An-Nur: 43)

3. Visual-Spatial Intelligence

Among the verses of the Qur'an that imply visual-spatial intelligence is the following surah Ar-Ra'du: 3:

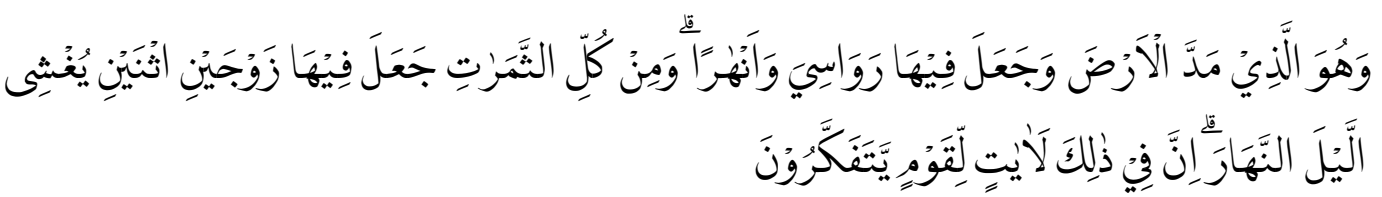

"And it was He who made the earth spread out wide, and made on its mountains (standing firm), and rivers (which flow), and of every kind of fruit. He made her a partner: two or two. He also protected day by night. All of them contain signs of Allah's power for the people who think." (Surah Ar-Ra'du: 3)

The above verse commands humans to see and reflect on the beauty of the universe created by Allah SWT. On another sheet, the Qur'an also reveals visual-spatial intelligence through surah Qaf: 7-8 as follows:

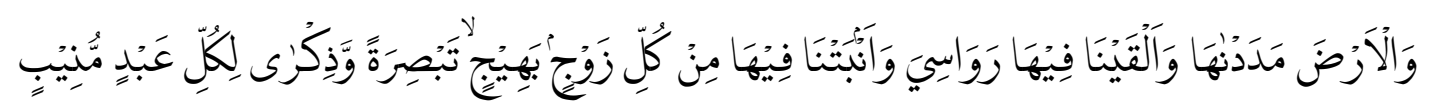


"And also (the state of) this earth, (how) We spread it out as a stretch, and We put on it the mountains that stand firm, and We grow on it various kinds of beautiful and fertile plants? (We do it all) to be a concern and warning (which shows the way of truth) to every servant of God who wants to return to Him (obediently and devotedly).

"(QS Qaf: 7-8)

4. Kinesthetic intelligence

Through, among other things, surah Al-Baqarah: 219, Al-Qur'an has provided instructions for humans to have kinesthetic intelligence of the body, by maintaining it, so that it is avoided from something harmful to it.

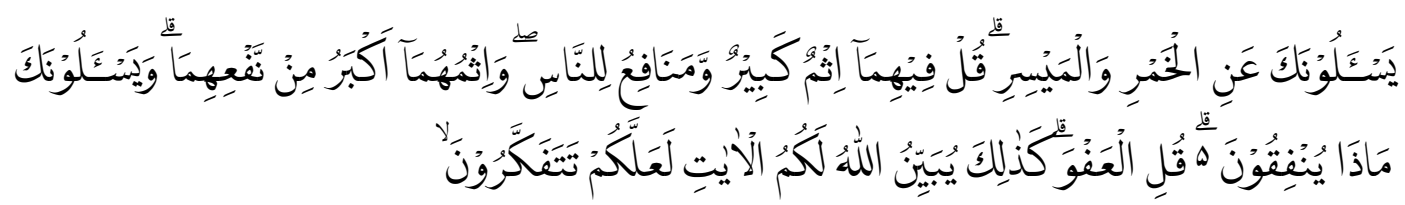

"They asked about wine and gambling. Say, in both of them, there are grave sins and some benefits for humans, but the sins of both are more significant than the benefits. Furthermore, they ask you, what do they support? Say, that is more than necessity. Thus Allah will explain His verses to you so that you may think." (Surah Al-Baqarah: 219)

Other signs about kinesthetic intelligence can be listened to in surah Yasin: 68 below:

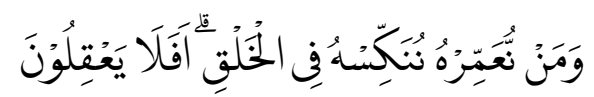

"And whomever We extend his age, We will undoubtedly return him to what happened. Then have they not thought." (QS Yasin: 68)

5. Musical Intelligence

In the Qur'an, there is no direct indication of musical intelligence. However, the order of words and sentences of the Al-Qur' an contains extraordinary great tone and style signals. The letters of the words of the Al-Qur'an give birth to a harmonious sound, and then the collection of words gives birth to the harmony of rhythm in a series of sentences of the verses, for example, surah An-Naziat below:

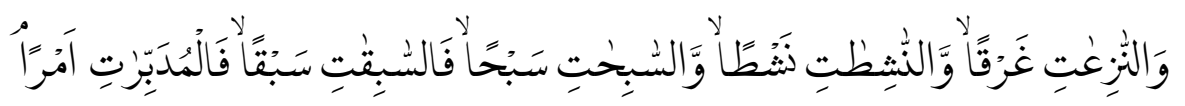

As soon as the hearing becomes accustomed to the above notes and styles, the Qur'an changes the tone and style. Listen to the follow-up verses: 


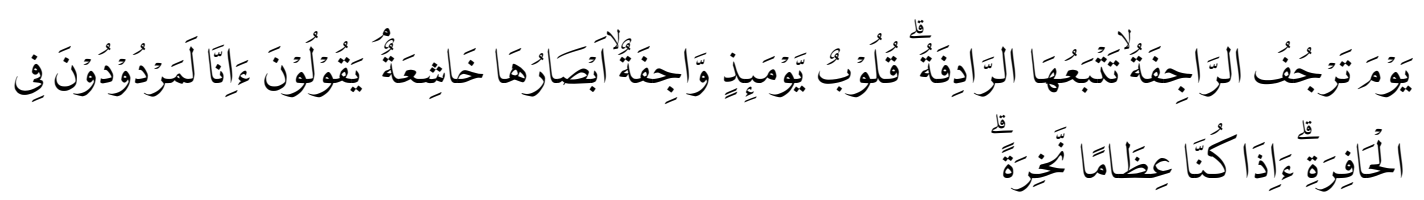

After that, he continued by changing the tone and style until this surah ended. Thus, although the signs of musical intelligence are not found explicitly in the Qur'an, the tone and style of the Qur'an itself have shown beauty, so that it can be categorized as the presence of musical intelligence. M Quraish Shihab quotes the English scholar, Marmaduke Pickthall, in The Meaning of the Glorious Qur'an, that the Qur'an has an incomparable symphony, where every note can move people to cry and rejoice. ${ }^{31}$

Meanwhile, concerning art activities in the form of poetry, in the tar sectionat the end of the Surah Asy-Syuara, there is an exciting illustration of poet artists or poets, most of whom are said to be heretical, except for poets who are faithful, do good deeds, and remember Allah a lot.

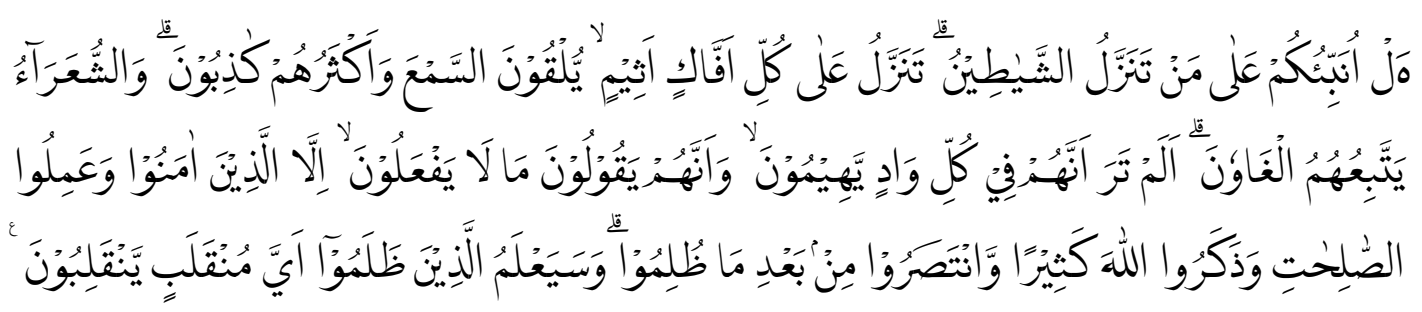

"Shall I tell you to whom the demons descended? They come down to every other liar who has many sins. They turn hearing (to the devil), and most of them are liars. Furthermore, those poets were followed by heretics. Do you not see that they wander in every valley?Moreover, they like to say what they do not do (it) except for people (poets) who believe and do good deeds and often chant Allah and get the victory after suffering injustice. Furthermore, those wrongdoers will know where they will return to." (Surah Asy-Syuara: 221-227)

6. Intrapersonal Intelligence

In the Qur'an, this intrapersonal intelligence can be understood, among other things, from Surah Adz-Dzariyat: 21 as follows:

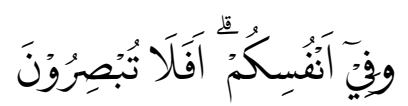

"And (also) to yourself, are you not paying attention." (Surah Adz-Dzariyat: 21)

\footnotetext{
${ }^{31}$ M Quraish Shihab, Mukjizat Al-Quran Ditinjau dari Aspek Kebahasaan, Isyarat Ilmiah, dan Pemberitaan Gaib (Bandung: Penerbit Mizan, 2004), 119.
} 
By using question sentences, Allah motivates humans always to try to know and recognize themselves. This self-knowledge is so important and central. If the man can know himself by thinking well, he can understand how it happened, for what reason he was created from sperm, then turned into a clot of blood, then turned into a lump of flesh. Including understanding the change from young to old. Everything happens not by itself, but it is all by the will of Allah.

Surah Al-Baqarah: 44 also encourages humans to have intrapersonal intelligence. Allah reminds humans to have the ability to introspect themselves and understand their rights and obligations.

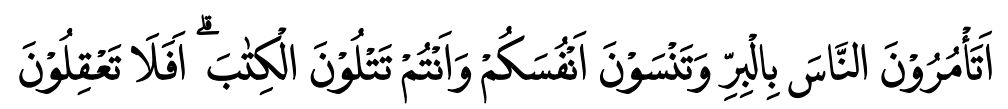

"Why do you tell other people to (do) goodness, while you forget yourself (obligation) yourself, even though you read the Al-Kitab (Torah)? Then don't you think." (Surah Al-Baqarah: 44)

In Surah Yasin: 62, Allah warns that humans can fortify themselves from Satan's temptations. Meanwhile, Surah Al-Mulk: 10 reminds people to use the potential of their intellect and hearing to improve the quality of faith before regretting it.

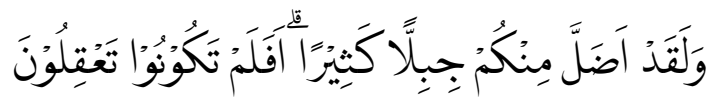

"Indeed, the devil has misled most of you, so do you not think?" (Surah Yasin: 62)

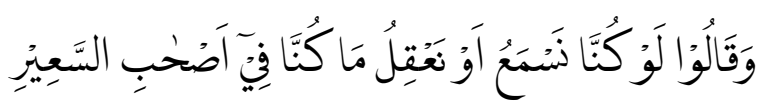

"And they said, if we listen to or think about (the warning), we certainly do not belong to the inhabitants of the burning hell." (Surah Al-Mulk: 10)

7. Interpersonal Intelligence

Among the verses of the Qur'an that indicate that humans have interpersonal intelligence is sura Ar-Rum: 21. Allah has reminded people who think that they have been given the blessings of love and affection; it must be appropriately managed. If they can manage emotions with love, control anger well, it will give birth to peace and tranquility.

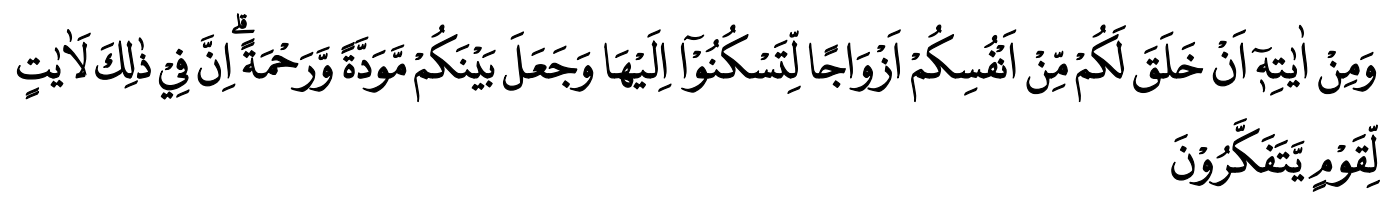


"And among the signs of His power is He created for you wives of your kind, so that you might be inclined and at ease with them, and made Him among you a sense of love and affection. Indeed in this, there are signs for the thinking people." (QS ArRum: 21)

Other signs conveyed by Allah in surah Al-Baqarah: 76 are as follows:

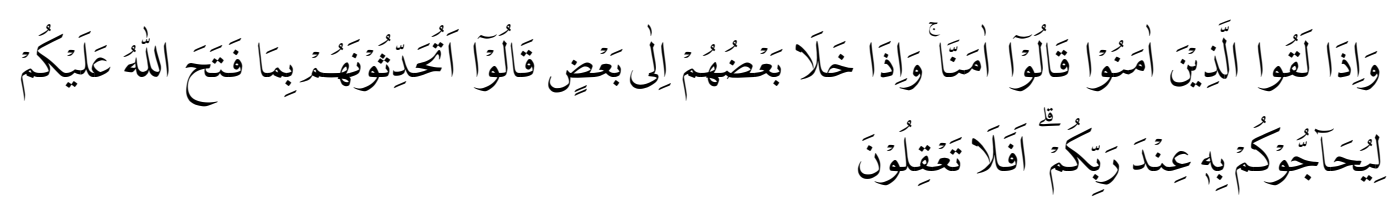

"And when they meet believers, they say, we have believed too. However, if they are among themselves, they say, do you tell them (the believers) what Allah has explained to you so that they can defeat your blasphemy before your Lord. Don't you understand?" (Surah Al-Baqarah: 76)

The above verse is the same as Allah's word in surah Ali Imran: 118, which encourages interpersonal intelligence, which means controlling and managing emotions when dealing with very dangerous hypocrites, even more, dangerous when compared to unbelievers.

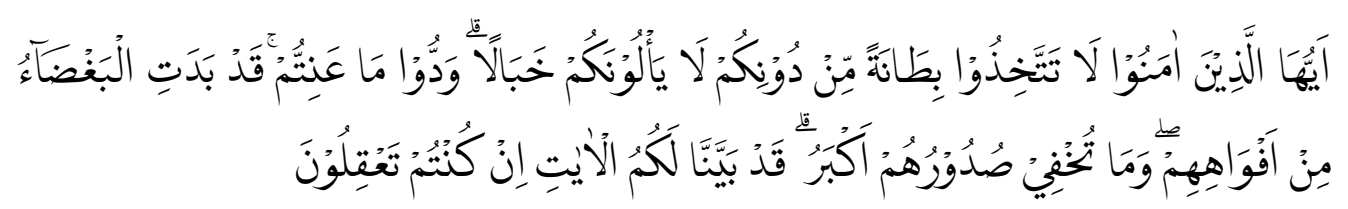

"O ye who believe! Do not take into your confidant friends those who, outside of your circle (because) they incessantly (cause) harm to you. They like what troubles you. Their mouths have shown hatred and what their hearts are hiding. Is even greater. Indeed We have explained to you (Our) verses if you understand them." (Surah Ali Imran: 118)

There are still many similar verses whose essence is to encourage humans to have intelligence in dealing with or dealing with others, including Surah Al-Baqarah: 197, Al-Hasyr: 2, At-Thalaq: 10, and others.

8. Naturalist Intelligence

There are countless verses of the Qur'an that contain this naturalist intelligence encouragement. Some of the Al-Qur'an explanations about nature, animals, and plants are so that humans have attention and knowledge about the real signs of Allah's greatness. Among these are the following verses: 


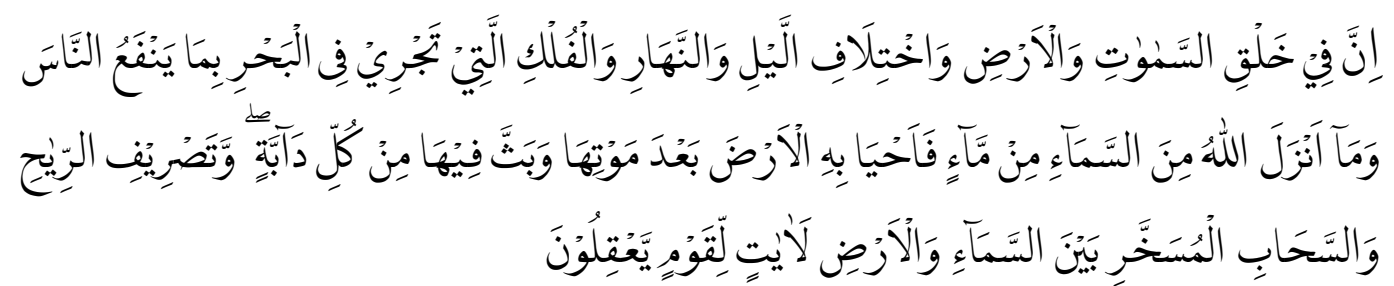

"In fact, in the creation of the heavens and the earth, the alternation of night and day, the ships that sail on the sea bring what is useful for humans, and what Allah sends down from the sky is water, then with that water He makes the earth live after it dies (dry) and He spreads on the earth all kinds of animals, and the controlled winds and clouds between the heavens and the earth, indeed (there are) signs (the oneness and greatness of Allah) for the people who think." (Surah Al-Baqarah: 164) There are signs about naturalist intelligence that can be understood from the word of God in surah An-Nahl: 11 below:

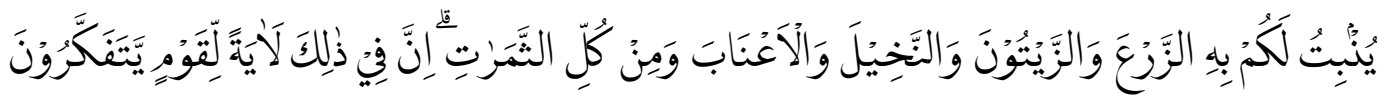

"He grows for you with the rainwater crops, olives, dates, grapes and all kinds of fruit. In fact, in that there is a sign (of Allah's power) for those who think." (Surah An-Nahl: 11)

Al-Quran signs that can also be associated with naturalist intelligence can be listened to in the following surah An-Nahl: 69:

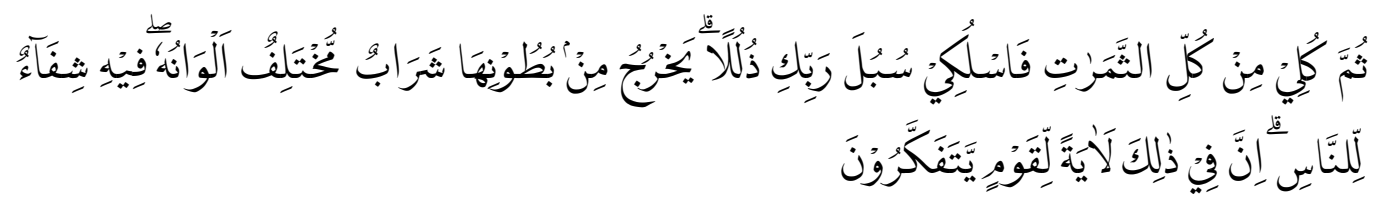

"Then eat of every (kind) of fruit and walk the path of your Lord, which has been facilitated (for you). From the bee's stomach comes a drink (honey) of various colors, in which there is healing medicine for humans. Surely in this, there is truly a sign (the greatness of God) for those who think." (Surah An-Nahl: 69)

The Qur'an does pay serious attention to natural and environmental problems. Among the evidence, pay attention to the word of God in surah Al-Ghasyiyah: 17 below:

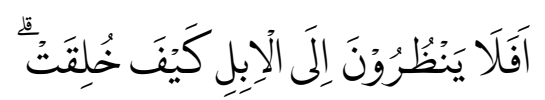

"Don't they pay attention to how the camel is created?" (Surah Al-Ghasyiyah: 17)

In the above verse, the Qur'an mentions camels, not other animals. The question of the Qur'an in the above verse shows the importance of paying attention to antique animals and their creative process and the uniqueness and benefits of these animals. 
Why does it have to be a camel? According to Yusuf Al-Qardhawi, because the camel is the animal most familiar with the life of the Arabs, the people to whom the Qur'an spoke before other nations. ${ }^{32}$ Thus, the Qur'an wants to remind the people it invokes about the animal resources that exist in their environment, with the hope that they will benefit from it and then be grateful for Allah's blessings.

9. Existentialist Intelligence

Through the Qur'an, Allah repeatedly reminds people to think intelligently, and by doing so, everything in the universe can increase human intelligence. Ability to read the signs of God's power and majesty.

Below the author quotes several verses of the Qur'an that can be categorized as implying existentialist intelligence or spiritual intelligence.

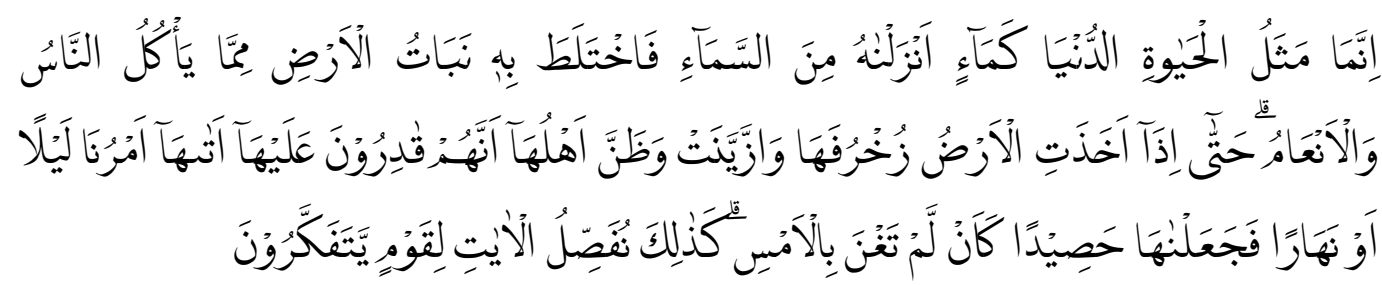

"Verily, the parable of worldly life is like water (rain) that We send down and the sky, and then flourish because the water is the plants of the earth, some of which are eaten by humans and livestock. So that when the earth is perfect in beauty and wears (also) its jewels, and its owners think that they will indeed dominate it, suddenly Our punishment comes to him at night or day, then We make (the plants) like plants sickled as if it had never grown yesterday. Thus We explain (Our) signs of power to the thinking people." (QS Yunus: 24)

Existentialist intelligence also enables the owner to grasp and understand the essence of life that everything is from and return to Allah.

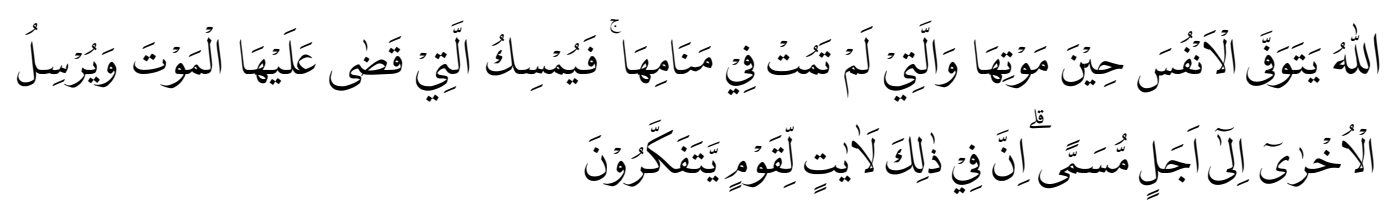

"Allah holds the soul (person) when he dies and (holds) the soul (person) who is not dead in his sleep. Then He endures the soul (person) whom He has ordained

\footnotetext{
${ }^{32}$ Yusuf Al-Qardhawi, As-Sunnah as a Source of Science and Technology and Civilization: The Discourse of Contextualization and Actualization of the Sunnah of the Prophet SAW in Science and Technology and Civilization (Jakarta: Pustaka Al-Kautsar, 1998), 174.
} 
death, and He releases another soul until the appointed time. Verily in this, there are signs of the power of Allah for the people who think." (QS Az-Zumar: 42)

This intelligence can also be called wisdom is given by Allah to whomever He wants, as one of the fruits of a servant's obedience in worship. With existentialist intelligence, the servant concerned can act wisely and understand correctly, entirely, and all the contents or messages of knowledge from the Al-Qur'an and the sunnah.

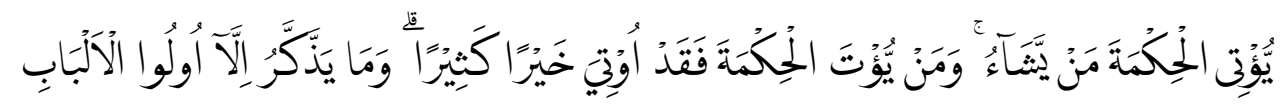

"Allah bestows al-hikmah (deep understanding of Al-Qur'an and As-Sunnah) to whomever He wants. Moreover, whoever is gifted with wisdom, he has been awarded many gifts. Furthermore, only those who have wisdom can take lessons (from the word of God)." (Surah Al-Baqarah: 269)

Based on the discussion about the verses of the Qur'an related to intelligence above, it was found that the Qur'an did not clearly define the meaning of intelligence. However, the meaning of intelligence in the Qur'an can be concluded through words that are widely used, and have a close meaning with intelligence. With the thematic interpretation method, the Qur'an's concept of multiple intelligences was discovered-as put forward by Howard Gardner from Harvard University - which consists of nine types of intelligence, namely linguistic intelligence, logical-mathematical intelligence, visualspatial intelligence, kinesthetic intelligence, intelligence, musical intelligence, intrapersonal intelligence, interpersonal intelligence, naturalist intelligence, existentialist intelligence.

In addition, the psychological concept of intelligence is very broad, and the Qur'an is truly a comprehensive book. The discovery of the perspective of the Quran on multiple intelligences also reinforces the view that humans are not only endowed with a single intelligence. In life and this complex life, a mere kind of intelligence will not be able to lead humans to achieve ideal dignity. Moreover, intellectual intelligence is not a guarantee for obtaining a better quality of faith or spiritual quality. With multiple intelligences, learning becomes fun and impressive, and saves students from the rigidity of educational concepts that only dwell on mathematics, logic, and language intelligence. Finally, the development of multiple intelligences in the perspective of the Quran in Islamic educational institutions. 


\section{Conclusion}

The Qur'an does not clearly define the meaning of intelligence. With the thematic interpretation method, the Qur'anic concept regarding multiple intelligences was found following: (1) deep linguistic intelligence An-Nisa: 82, Al-Baqarah: 171, Al-An'am: 50, Ali Imran: 7; (2) Logical-mathematical intelligence in Al-Waqiah: 58-59, Al-Insan: 2, Ar-Ra'du: 3, Al-Anbiya: 30, An-Nur: 43; (3) visual-spatial intelligence in Ar-Ra'du: 3, Qaf: 7-8; (4) kinesthetic intelligence in Al-Baqarah: 219, Yasin: 68; (5) musical intelligence in AsySyuara: 221-227; (6) intrapersonal intelligence in Adz-Dzariyat: 21, Al-Baqarah: 44, Yasin: 62, Al-Mulk: 10; (7) interpersonal intelligence in Ar-Rum: 21, Al-Baqarah: 76, Ali Imran: 118; (8) naturalist intelligence in Al-Baqarah: 164, An-Nahl: 11, An-Nahl: 69, AlGhasyiyah: 17; (9) existentialist intelligence in Yunus: 24, Az-Zumar: 42, Al-Baqarah: 269.

Some suggestions that the researchers propose related to the theme of multiple intelligence according to the perspective of the Qur'an are (1) Educational institutions should add new insights regarding their learning strategies with multiple intelligences, especially those whose source of inspiration is the Qur'an. (2) For other researchers who want to study the same theme, researchers suggest examining the concept of musical intelligence in the Qur'an. Because besides there are no clear verses that point to this, there is also a musical issue, there are differences of opinion among Muslims. (3) Assessing interpersonal intelligence, especially those related to the concept of multiculturalism, needs to be researched. (4) Naturalist intelligence needs to be studied further, especially in relation to efforts to conserve the environment and natural resources.

\section{References}

Abdullah, Azis. "Perbandingan Kecerdasan Majemuk (Perspektif Al-Quran dan Barat)." AlManar: Jurnal Komunikasi dan Pendidikan Islam, Volume 7, Nomor 2, Desember 2018: 23-40, https://doi.org/10.36668/jal.v7i2.88.

Agustian, Ary Ginanjar. Rahasia Sukses Membangun Kecerdasan Emosi dan Spiritual ESQ (Emotional Spiritual Quotient) Berdasarkan 6 Rukun Iman dan 5 Rukun Islam. Jakarta: Penerbit Arga, 2001.

Arikunto, Suharsimi. Prosedur Penelitian: Suatu Pendekatan Praktek. Jakarta: Rineka Cipta, 1990.

Baharuddin. Paradigma Psikologi Islami: Studi tentang Elemen Psikologi dari Al-Quran. Yogyakarta: Pustaka Pelajar, 2007.

Chatib, Munif dan Alamsyah Said, Sekolah Anak-Anak Juara Berbasis Kecerdasan Jamak dan Pendidikan Berkeadilan. Bandung: Kaifa, 2012.

Chatib, Munif. Sekolahnya Manusia: Sekolah Berbasis Multiple Intelligences di Indonesia. Bandung: Kaifa, 2014. 
Faisol, Sanapiah. Format-Format Penelitian Sosial. Jakarta: Rajawali Press, 1992.

Gardner, Howard. Multiple Intelligences (Kecerdasan Majemuk): Teori dalam Praktik. Tangerang: Interaksara, 2013.

Goleman, Daniel. Working with Emotional Intelligence. London: Bloomsbury Publishing, 2009.

Hadi, Sutrisno. Metodologi Research. Yogyakarta: Andi Offset, 1995.

Hofur. "Konsep Multiple Intelligences Perspektif Al-Quran/Hadis dan Implikasinya terhadap Pembelajaran PAI." Skripsi, Jurusan Pendidikan Agama Islam Fakultas Tarbiyah dan Ilmu Pendidikan UIN Sunan Kalijaga Yogyakarta, 2018.

Ma'ruf, Muhammad Anas dan Eka Deni Sulistyanik. "Pengembangan Potensi Peserta Didik dalam Pembelajaran Pendidikan Agama Islam Berbasis Kecerdasan Majemuk (Multiple Intelligence)." Al-Tarbawi Al-Haditsah: Jurnal Pendidikan Islam, Vol. 4, No. 2, Desember 2019: 81-105, DOI: 10.24235/tarbawi.v4i2.5216.

Masjudin dan Syahyudin. "Teori Kecerdasan Majemuk (Multiple Intelligence) dan Teori Kecerdasan Emosi (Emotional Intelligence) serta Relevansinya dengan Konsep Pendidikan Islam." Ta'dib, Volume 15, No I (Jan-Juni 2017): 73-75. https://jurnal.iaihnwpancor.ac.id/index.php/tadib/article/view/179.

Moeloeng, Lexy J.. Metodologi Penelitian Kualitatif. Bandung: Remaja Rosdakarya, 2003.

Muhadjir, Noeng. Metodologi Penelitian Kualitatif. Yogyakarta: Penerbit Rake Sarasin, 2000.

Nata, Abuddin. Metodologi Studi Islam. Jakarta: Raja Grafindo Persada, 2002.

Qardhawi, Yusuf Al-. As-Sunnah sebagai Sumber Iptek dan Peradaban: Diskursus Kontekstualisasi dan Aktualisasi Sunnah Nabi SAW dalam Iptek dan Peradaban. Jakarta: Pustaka Al-Kautsar, 1998.

Rakhmat, Jalaluddin. Konsep-Konsep Antropologi dalam Budhy Munawar-Rachman (ed.), Kontekstualisasi Doktrin Islam dalam Sejarah. Jakarta: Paramadina, 1995.

Shabuni, Muhammad Ali Al-. Shafwah Al-Tafasir, Juz I. Beirut: Dar Al-Fikr, 1988.

Shihab, M Quraish. Kaidah Tafsir: Syarat, Ketentuan, dan Aturan yang Patut Anda Ketahui dalam Memahami Ayat-Ayat Al-Qur'an. Tangerang: Lentera Hati, 2013.

Shihab, M Quraish. Mukjizat Al-Quran Ditinjau dari Aspek Kebahasaan, Isyarat Ilmiah, dan Pemberitaan Gaib. Bandung: Penerbit Mizan, 2004.

Sibilana, Annas Ribab. "Pendidikan Karakter Melalui Pembelajaran Berbasis Multiple Intelligences di Markaz Arabiyah Pare Kediri." Indonesian Journal of Islamic Education Studies (IJIES), Volume 3, Nomor 1, Juni 2020: 48-62. https://doi.org/10.33367/ijies.v3i1.1123.

Suprayogo, Imam dan Tobroni. Metodologi Penelitian Sosial-Agama. Bandung: Remaja Rosdakarya, 2003.

Yaumi, Muhammad. Pembelajaran Berbasis Multiple Intelligencesi. Jakarta: Dian Rakyat, 2012. 